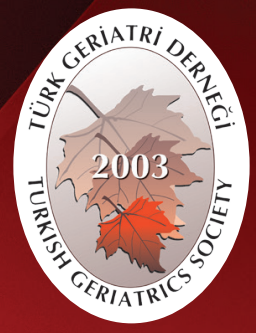

Turkish Journal of Geriatrics

DOI: 10.31086/tigeri.2018240427

2018:21 (2):263-270

- Adem ÇÖBDEN ${ }^{1}$

- İsmet Yalkın ÇAMURCU²

- Hanifi ÜÇPUNAR ${ }^{3}$

- Hakan SOFU ${ }^{4}$

- Serda DUMAN ${ }^{5}$

\title{
EVALUATION OF RISK FACTORS FOR OSTEOPOROSIS AND OSTEOPENIA IN MALE PATIENTS AGED OVER 60 YEARS OF AGE
}

\section{Abstract}

Introduction: Osteoporosis in men is often underdiagnosed and neglected compared to postmenopausal women. Major risk factors should be determined to prevent this disease, which has potential risk of mortality and morbidity for elder men. This study's purpose was to determine the risk factors for osteoporosis and osteopenia in male patients aged $>60$ years.

Materials and Method: Between January 2015 and June 2017, male patients aged $>60$ years admitted to our centers who underwent dual energy $x$-ray absorptiometry (DXA) were included in this retrospective study. Patients' age, body mass index, site of residence (village/ city), smoking status, and systemic diseases were examined through our records. Patients were divided into control, osteopenia, and osteoporosis groups according to DXA measurements. Serum vitamin D measurements also were evaluated. Multivariate analysis was performed to determine major risk factors for osteoporosis and osteopenia.

Results: Compared with the control group, patients in the group categorized as having osteoporosis or osteopenia had a significantly lower body mass index and more commonly resided in the city $(p<0.001$ and $p<0.005$, respectively). Serum vitamin $D$ levels were significantly lower in the osteoporosis and osteopenia groups than in the control group $(p=0.001)$. According to multivariate analysis, insufficient or deficient serum vitamin $D$ levels were determined to be a major risk factor for osteoporosis and osteopenia ( $p=0.001)$.

Conclusion: According to our results, men aged $>60$ years with deficient serum vitamin $D$ levels $(<20 \mathrm{ng} / \mathrm{mL})$ were six times more likely to have osteopenia and 80 times more likely to have osteoporosis.

Keywords: Osteoporosis; Bone diseases, Metabolic; Bone density; Risk factors; Vitamin D
CORRESPONDANCE

İsmet Yalkın ÇAMURCU

Erzincan University, Faculty of Medicine,

Department of Orthopaedics and Traumatology

Erzincan, Turkey

Phone: 05334802310

e-mail: yalkin.camurcu@gmail.com

Received: 04/01/2018

Accepted: 05/03/2018

Sivas Numune Hospital, Department of Orthopaedics and Traumatology,

Sivas, Turkey

Erzincan University, Faculty of Medicine,

Department of Orthopaedics and Traumatology

Erzincan, Turkey

Erzincan University, Faculty of Medicine,

Department of Orthopaedics and

Traumatology, Erzincan, Turkey

${ }^{4}$ Erzincan University, Faculty of Medicine,

Department of Orthopaedics and Traumatology

${ }^{5}$ Diyarbakır Selahaddin Eyyubi State

Hospital, Department of Orthopaedics and

Traumatology, Diyarbakır, Turkey
ARAŞTIRMA

\section{ALTMIŞ YAŞ ÜZERI ERKEK HASTALARDA OSTEOPOROZ VE OSTEOPENI RISK FAKTÖRLERININ DEĞERLENDIRILMESi}

\section{$\ddot{O}_{z}$}

Giriş: Erkeklerde osteoporoz postmenopozal kadınlara kıyasla çoğunlukla az tanı alır ve ihmal edilir. Yaşlı erkeklerde potansiyel mortalite ve morbidite riski taşıyan bu hastalığı önlemek için başlıca risk faktörleri belirlenmelidir. Bu çalışmanın amacı, 60 yaş üzerindeki erkek hastalarda osteoporoz ve osteopeni için risk faktörlerini belirlemektir.

Gereç ve Yöntem: Ocak 2015- Haziran 2017 tarihleri arasında merkezlerimize başvuran ve Dual Enerji X-ray Absorptiometri (DXA) ölçümleri yapılan 60 yaş üzeri erkek hastalar bu retrospektif çalışmaya dahil edildi. Hastaların yaşı, beden kütle indeksi (BKI), yerleşim yeri (köyşehir), sigara içme durumu ve sistemik hastalıkları kayıtlarımızdan incelendi. Hastalar DXA ölçümlerine göre kontrol, osteopeni ve osteoporoz olarak 3 gruba ayrıldı. Hastaların serum vitamin D ölçümleri de değerlendirildi. Osteoporoz ve osteopeni için temel risk faktörlerini belirlemek için çok değişkenli analiz uygulandı.

Bulgular: Kontrol grubuyla karşılaştırıldığında, osteoporoz veya osteopeni grubundaki hastalarda VKI anlamlı derecede düşüktü ve bunlar daha çok şehirde yerleşikti (sırasıyla $p<0.001$ ve 0.005 ). Serum vitamin D seviyeleri osteoporoz ve osteopeni gruplarında kontrol grubuna göre anlamlı düşüktü ( $p=0.001)$. Çok değişkenli analize göre, yetersiz veya eksik serum vitamin $D$ seviyeleri osteoporoz ve osteopeni için temel risk faktörleri olarak belirlendi ( $p=0.001$ ).

Sonuç: Sonuçlarımıza göre, serum vitamin $D$ düzeyleri yetersiz olan 60 yaşın üzerindeki erkeklerde ( $<20 \mathrm{ng} / \mathrm{mL}$ ) osteopeni tanısı olasılığının 6 kat, osteoporoz tanısı olasılığının 80 kat fazla olduğu görülmüştür.

Anahtar sözcükler: Osteoporoz; Kemik hastalıklarl; metabolik; Kemik dansite; Risk faktörleri; Vitamin D 


\section{INTRODUCTION}

Osteoporosis is the most common metabolic bone disease, characterized by decreased bone mass and microarchitectural deterioration of the bone tissue, with consequent increases in bone fragility and fracture susceptibility $(1,2)$. The prevalence of osteoporosis in male patients aged $>60$ years was reported at $13 \%$, which increases to $70 \%$ at age $\geq 80$ years (3-5). Of the 9.0 million new osteoporotic fractures that occurred worldwide in 2000, 39\% occurred in men, and $45 \%$ of these fractures occurred in the areas frequently affected by osteoporosis (6).

Various risk factors for osteoporosis have been reported, including race, heredity, age, gender, family history, low bone mineral density (BMD), vitamin D deficiency, smoking, low physical activity, and body mass profile (7). Investigators attempt to decrease the number of male patients with osteoporosis using the appropriate strategies and early intervention for preventable factors. Although, there are numerous studies about male osteoporosis exist in the literature; some studies reported that osteoporosis in elder men is still underdiagnosed and neglected (8-11).

Dual energy X-ray absorbtiometry (DXA) is recommended for osteoporosis in men aged 70 years and older but supportive data is limited $(12,13)$. Male osteoporosis is becoming an increasingly common condition with subsequent mortality and mortality (14). Healthcare providers should consider annual screening for osteoporosis in men as equal as routine prostate and colorectal screening. In addition to that, independent major risk factors should be determined for elder men to prevent this disease, which has potential risk of mortality and morbidity. Therefore, the aim of this study was to determine the main risk factors for osteoporosis in male patients aged $>60$ years.

\section{MATERIALS AND METHOD}

This multicenter retrospective study was conducted with the approval of the institutional ethical review board (University Clinical Researches Ethical Review Board, ID=42914) and performed in accordance with the Declaration of Helsinki. To obtain a standardized data evaluation, this study was performed at two centers using the same manufacturer's DXA devices and located in the same areas of sun exposure. Male patients aged $>60$ years who were admitted to the two centers from January 2015 to June 2017 and underwent DXA and laboratory tests were reviewed from our electronical medical records. Patients with known history of metabolic bone diseases, taking any form of medication for osteoporosis or osteopenia, under follow-up at the endocrinology department due to secondary osteoporosis or osteomalacia were excluded. After exclusions, the data of 460 patients were evaluated in this study.

Patients' age, gender, body mass index (BMI), site of residence (village or city), smoking status, and systemic diseases were reviewed from our electronical medical records. Patients' BMls were classified according to World Health Organization classification as underweight $(<18.5$ $\left.\mathrm{kg} / \mathrm{m}^{2}\right)$, normal $\left(18.5-24.5 \mathrm{~kg} / \mathrm{m}^{2}\right)$, overweight $\left(25-29.9 \mathrm{~kg} / \mathrm{m}^{2}\right)$, class-I obesity $\left(30-34.9 \mathrm{~kg} / \mathrm{m}^{2}\right)$, class-II obesity $\left(35-39.9 \mathrm{~kg} / \mathrm{m}^{2}\right)$, and class-III extreme obesity $\left(>40 \mathrm{~kg} / \mathrm{m}^{2}\right)$. Systemic comorbid diseases were hypertension, hyperlipidemia, cardiovascular system disease (coronary artery disease and congestive heart failure), respiratory system disease (asthma, chronic obstructive lung disease), diabetes mellitus, gastrointestinal system disease (peptic ulcus, irritable bowel syndrome, celiac disease), neurological system disease (cerebrovascular disease, Parkinson 
disease, epilepsy, Alzheimer disease, depression), and rheumatological disease (rheumatoid arthritis, ankylosing spondylitis).

All subjects underwent measurement of BMD $\left(\mathrm{kg} / \mathrm{cm}^{2}\right)$ using the same DXA devices (STRATOS $d R$, DMS, Maugio, France) at the anteroposterior lumbar spine (L1-L4) and at the femoral neck as per standard protocol stated by the manufacturer. Patients' were primarily divided into one of three groups according to $T$ scores established by World Health Organization classification as control $(>-1)$, osteopenia $(-1$ to -2.5$)$, and osteoporosis $(<-2.5)$. Serum levels of vitamin $D[25(\mathrm{OH}) \mathrm{D}]$ were measured by radio-immuneassay (RIA) method by using the same kits in both two centers. Serum vitamin D levels classified as adequate $(>30 \mathrm{ng} / \mathrm{mL})$, insufficient $(21-29 \mathrm{ng} / \mathrm{mL})$, or very deficient $(<20 \mathrm{ng} / \mathrm{mL}$ ). Serum calcium (Ca) and phosphor (P) levels were also reviewed for all patients, which were analyzed by calorimetric method. The normal laboratory ranges for serum Ca was 8.8-10.6 mg/dl and for serum $P$ was 2.3$5 \mathrm{mg} / \mathrm{dl}$. Those with impaired serum $\mathrm{Ca}$ and $\mathrm{P}$ values were routinely consulted to endocrinology department and excluded from the study to keep apart osteomalacia and secondary osteoporosis as mentioned above.

Statistical analysis was performed using SPSS 20.0 (SPSS Inc., IBM, NY, USA). Numeric variables were given as means and standard deviation; categorical variables were given as frequency and percentage. The comparison of the three study groups was performed using One-way analysis of variance (ANOVA) for means, and with Chi-square test for frequencies.
Bonferroni or Tamhane's $t^{2}$ tests were used for comparison between groups. P values of $<0.05$ were considered statistically significant. Finally, multivariate regression analysis was performed to determine the main risk factors for osteoporosis and osteopenia.

\section{RESULTS}

The demographics of the three study groups as well as of systemic comorbid diseases, serum vitamin $\mathrm{D}$ levels, and BMD values are shown in Table 1. No significant difference was observed among the three groups in terms of age, smoking status, and systemic comorbid diseases. The osteoporosis and osteopenia groups had significantly lower $\mathrm{BMI}$ values than the control group ( $p=<0.001$ and $p=<0.001$, respectively). In addition, patients diagnosed with osteoporosis and osteopenia were significantly more likely to be living in a city than patients in the control group $(p=0.005)$. Serum vitamin $D$ levels, BMD values, and $t$ scores were significantly lower in patients in the osteoporosis and osteopenia groups than in patients in the control group, as expected.

According to multivariate regression analysis, insufficient and deficient serum vitamin $D$ levels were determined as the main risk factors for osteoporosis and osteopenia in male patients aged $>60$ years (Table 2). According to our results, males aged $>60$ years with deficient serum vitamin $D$ levels $(<20 \mathrm{ng} / \mathrm{mL})$ were six times more likely to have osteopenia and 80 times more likely to have osteoporosis. 
Table 1. Demographics and clinical characteristics of study groups.

\begin{tabular}{|c|c|c|c|c|}
\hline & $\begin{array}{l}\text { Normal } \\
(n=179)\end{array}$ & $\begin{array}{r}\text { Osteopenia } \\
(n=201)\end{array}$ & $\begin{array}{r}\text { Osteoporosis } \\
(n=80)\end{array}$ & p \\
\hline Age (years) & $67.0 \pm 8.5$ & $68.8 \pm 9.7$ & $68.7 \pm 9.2$ & 0.154 \\
\hline BMI $\left(\mathrm{kg} / \mathrm{m}^{2}\right)$ & $29.6 \pm 4.3$ & $27.9 \pm 4.2$ & $26.5 \pm 5.1$ & $<0.001$ \\
\hline BMI (WHO Classification) & & & & $<0.001$ \\
\hline Underweight & $1(0.5 \%)$ & $2(1 \%)$ & $7(8.7 \%)$ & \\
\hline Normal & 35 (19.6\%) & $66(32.9 \%)$ & $32(40 \%)$ & \\
\hline Overweight & $69(38.5 \%)$ & $78(38.8 \%)$ & $24(30 \%)$ & \\
\hline Class I & $40(22.4 \%)$ & $28(13.9 \%)$ & $9(11.2 \%)$ & \\
\hline Class III & $31(17.3 \%)$ & $24(11.9 \%)$ & $6(7.5 \%)$ & \\
\hline Class III & $3(1.7 \%)$ & $3(1.5 \%)$ & $2(2.6 \%)$ & \\
\hline Site of Residence & & & & 0.005 \\
\hline City & 95 (53\%) & $127(63.2 \%)$ & 59 (73.7\%) & \\
\hline Village & $84(47 \%)$ & 74 (36.8\%) & $21(26.3 \%)$ & \\
\hline Smoking Status & & & & 0.363 \\
\hline None & $137(76.5 \%)$ & $153(76.1 \%)$ & $55(68.7 \%)$ & \\
\hline Smoking & $42(23.5 \%)$ & $48(23.9 \%)$ & $25(31.3 \%)$ & \\
\hline \multicolumn{5}{|l|}{ Systemic Comorbid Disease (+/-) } \\
\hline Hypertension & $88 / 91$ & 106/95 & $42 / 38$ & 0.764 \\
\hline Hyperlipidemia & $10 / 169$ & $5 / 196$ & $1 / 79$ & 0.126 \\
\hline Cardiovascular disease & $19 / 160$ & 16/185 & $6 / 74$ & 0.589 \\
\hline Respiratory system disease & $41 / 138$ & $47 / 154$ & $25 / 55$ & 0.309 \\
\hline Diabetes mellitus & 18/161 & $12 / 189$ & $6 / 74$ & 0.332 \\
\hline Gastrointestinal system disease & $2 / 177$ & $9 / 192$ & $4 / 76$ & 0.115 \\
\hline Neurologic system disease & $16 / 163$ & $17 / 184$ & $7 / 73$ & 0.986 \\
\hline Rheumatologic disease & $1 / 178$ & $3 / 198$ & $0 / 80$ & 0.405 \\
\hline Serum Vitamin D Level & & & & $<0.001$ \\
\hline Adequate & 118 & 41 & 5 & \\
\hline Insufficient & 42 & 115 & 26 & \\
\hline Deficient & 19 & 45 & 49 & \\
\hline $\operatorname{BMD}\left(\mathrm{kg} / \mathrm{cm}^{2}\right)$ & $1.08 \pm 0.07$ & $0.88 \pm 0.05$ & $0.72 \pm 0.07$ & $<0.001$ \\
\hline T score (lumbar) & $0.1 \pm 1.1$ & $(-) 1.4 \pm 0.7$ & $(-) 2.9 \pm 0.6$ & $<0.001$ \\
\hline T score (femur neck) & $(-) 0.2 \pm 1.0$ & $(-) 1.3 \pm 0.9$ & $(-) 1.9 \pm 1.2$ & $<0.001$ \\
\hline
\end{tabular}

BMD: bone mineral density, BMI: body mass index, WHO: world health organization 
Table 2. The major risk factors for osteopenia and osteoporosis according to multivariate regression analysis.

\begin{tabular}{lllrlr}
\hline \multirow{2}{*}{ Study Group } & & & \multicolumn{2}{c}{ Multivariate regression analysis } & \\
\cline { 3 - 5 } & Variable & Level & Odds ratio & $\begin{array}{r}(95 \% \\
\text { Confidence Interval) }\end{array}$ & $p$ \\
\hline \multirow{2}{*}{ Osteopenia } & & Insufficient & $8.1(4.8-13.6)$ & $<0.001$ \\
& Vitamin D & Deficient & $6.8(3.5-13.2)$ & $<0.001$ \\
\hline \multirow{2}{*}{ Osteoporosis } & Vitamin D & Insufficient & $17.6(5.7-54.2)$ & $<0.001$ \\
& Vitamin D & Deficient & $80.5(25.4-254.5)$ & $<0.001$ \\
\hline
\end{tabular}

\section{DISCUSSION}

The most significant finding of our study was that insufficient or deficient serum vitamin $D$ levels are the major risk factors for osteoporosis or osteopenia in male patients aged $>60$ years. Previous clinical studies widely investigated the risk factors for osteoporosis in men. Cheung et al. evaluated the determinants of BMD in Chinese men and authors reported that age, weight, BMl, cigarette smoking and exercise were significant determinants of total hip BMD. Authors found that body weight was the most important determining factor (15). The positive correlation of low BMl and low BMD for post-menopausal women has also been reported in previous clinical studies (16). Villareal et al. observed that diet-induced weight loss in elderly adults increased bone turnover and decreased hip BMD (17). In another study by Boyanov et al., BMD values for 80 male patients diagnosed with metabolic syndrome were found to be significantly higher than values for a control group (18). Yang et al. also emphasized the importance of diet as determinant of BMD values in their study evaluating 2305 male aged 50 to 79 years (19). Despite having higher BMI values in our country compared to eastern countries such as China and Korea; we also found significantly lower BMI values in osteopenia and osteoporosis groups compared with a control group, similar to results from reported studies. Our results showed that $80 \%$ patients were overweight or obese in the control group; however, $50 \%$ patients were overweight or obese in the osteoporosis group.

Smoking is another risk factor, which has been found to correlate with decreased $\operatorname{BMD}(20,21)$. Oncken et al. investigated smoking cessation and found a significant increase in femur neck BMD measurements 1 year after cessation of smoking cigarettes (22). According to our results, smoking status did not differ among groups; however, we did not have data about number of cigarette smoked per day and duration of smoking, which may influence the results.

Pagonis et al. reported that osteoporotic fracture patterns in urban patients are more severe, which is explained by decreased activity level and poor quality of life (23). In the same study, the authors stated that people living in rural areas had a later diagnosis of osteoporosis, and had better treatment outcomes (23). Men aged $>60$ years living in rural areas are more active than their urban counterparts, because of work and environmental conditions (24). Consistent with results from the literature, our findings indicated that $74 \%$ male patients diagnosed with osteoporosis lived in the city, while the remaining $26 \%$ lived in villages. However, in the control group, half of the patients lived in the city. 
Clinical studies about systemic comorbid diseases and drug use revealed that $90 \%$ patients with osteoporosis have a chronic disease and onethird of them use a drug that can cause osteoporosis (25). In studies evaluating systemic comorbid diseases related to osteoporosis, hypertension and diabetes were found as most commonly associated with osteoporosis (26). In our study, the most common systemic comorbid disease was found to be hypertension in both groups. Respiratory system disease such as chronic obstructive lung disease and asthma were the second-most common systemic comorbid diseases in both groups. We found no relationship between systemic comorbid diseases and lower BMD values. Our study had no data about the drug use that may also cause secondary osteoporosis. Most studies in the literature investigated male osteoporosis by excluding systemic comorbid diseases. However, we believe that rather than evaluation of healthy elder people, evaluation of elder people with systemic comorbid diseases may give valuable information about the real incidence of disease and may demonstrate the main characteristics of population accurately.

To our knowledge, vitamin D provides an important contribution to skeletal calcium balance by increasing intestinal and renal calcium absorption. It was stated that the shade of clothing, duration of exposure to direct sunlight, and regional climatic characteristics could affect vitamin $D$ levels. A positive correlation also was found between duration of sunshine exposure and vitamin D level (27). However, the prevalence of vitamin $\mathrm{D}$ deficiency is high worldwide even in tropical regions (28). Most studies about male osteoporosis have indicated that vitamin $D$ deficiency is a substantial risk factor for the reduction of BMD and the development of osteoporosis. Moreira et al evaluated healthy men in Brazil and authors found a high prevalence of vitamin D deficiency and its relation to increased osteoporosis (28). Khashayar et al reported significant correlation of vitamin $\mathrm{D}$ deficiency and BMD in healthy Iranian men (29). Sundh et al emphasized that serum vitamin $D$ is associated with higher cortical porosity in elderly men (30). Other studies also revealed the importance of vitamin $D$ deficiency in male osteoporosis $(12,15,19,31)$. The provinces where our study was performed are disadvantaged areas in terms of climate characteristics and insufficient sun exposure, when evaluated with regard to vitamin $D$ synthesis. According to multivariate regression analysis, we found insufficient and deficient serum vitamin $D$ levels to be the main predictive factors for the diagnosis of osteopenia and osteoporosis in our study. Our results also are consistent with previous community-based studies. Considering data obtained from our study, clinicians should attempt to prevent osteoporosis and osteopenia by investigating serum vitamin $D$ levels in elderly patients.

The main limitation of our study was its retrospective design, which may strongly influence determining risk factors accurately. However, we evaluated a relatively large homogenous ( $>60$ years old male patients) patient data collected from two centers with a standardized method. In addition, we performed a multivariate regression analysis to determine the major risk factors for osteopenia and osteoporosis with odds ratios. The most important strength of our study was that it is the first study in our country reporting major risk factors for osteoporosis and osteopenia in male patients aged $>60$ years. In addition, the importance of serum vitamin $D$ level deficiency was also shown in this study.

According to our results, males aged $>60$ years with deficient serum vitamin $D$ levels $(<20 \mathrm{ng} /$ $\mathrm{mL}$ ) were six times more likely to have osteopenia and 80 times more likely to have osteoporosis. Physicians should take into account the importance of serum vitamin D deficiency in elderly men and its significant relation with osteoporosis which can cause mortality and morbidity. 


\section{REFERENCES}

1. Warriner AH, Saag KG. Osteoporosis diagnosis and medical treatment. Orthop Clin North Am 2013;44:125-35. (PMID:23544819).

2. Erkin G, Akınbingöl M, Gülsen ED, Aybay C, Özel $S$. The features of the geriatric patients who have bone mineral dansitometric measurements in our osteoporosis unit. Turkish Journal of Geriatrics 2004; 7:84-8.

3. Randell A, Sambrook PN, Nguyen TV, et al. Direct clinical and welfare costs of osteoporotic fractures in elderly men and women. Osteoporos Int 1995;5(6):427-32. (PMID:8695963).

4. Johnell $O$, Kanis JA. An estimate of the worldwide prevalence and disability associated with osteoporotic fractures. Osteoporos Int 2006;17(12):1726-33. (PMID:16983459).

5. Brauer CA, Coca-Perraillon M, Cutler DM, Rosen $A B$. Incidence and mortality of hip fractures in the United States. JAMA 2009;14;302(14):1573-9. (PMID:19826027).

6. Burge R, Dawson-Hughes B, Solomon DH, Wong JB, King A, Tosteson A. Incidence and economic burden of osteoporosis-related fractures in the United States, 2005-2025. J Bone Miner Res 2007;22(3):46575. (PMID:17144789).

7. Unni S, Yao Y, Milne N, Gunning K, Curtis JR, LaFleur $J$. An evaluation of clinical risk factors for estimating fracture risk in postmenopausal osteoporosis using an electronic medical record database. Osteoporos Int 2015;26(2):581-7. (PMID:25288442).

8. Haas ML, Moore K. Osteoporosis: an invisible, undertreated, and neglected disease of elderly men. J Elder Abuse Negl 2007;19(1-2):61-73. (PMID:18077270).

9. Goh LH, How CH, Lau TC. Male osteoporosis: clinical approach and management in family practice. Singapore Med J 2014;55(7):353-7. (PMID:25091882).

10. Bleicher $K$, Naganathan $V$, Cumming RG, et al. Prevalence and treatment of osteoporosis in older Australian men: findings from the CHAMP study. Med J Aust 2010;193(7):387-91. (PMID: 20919967).

11. Rasheed M, Kaim Khani GM, Rasheed N. Awareness of osteoporosis in men. J Pak Med Assoc 2015;65(11 Suppl 3):S12-6. (PMID: 26878501).
12. Bhat KA, Kakaji M, Awasthi A, et al. High prevalence of osteoporosis and morphometric vertebral fractures in Indian males aged 60 years and above: should age for screening be lowered? J Clin Densitom 2016 Nov 30. pii: S1094-6950(16)30242-6. (PMID:27914693).

13. Khatib J, Stote K, Gosmanov AR. Utility of DXA screening for diagnosis of osteoporosis in US veterans aged 70 years and older. J Investig Med 2017 Oct 2. pii: jim-2017-000557. (PMID:28974557).

14. Tuzun S, Eskiyurt N, Akarirmak U, et al. Incidence of hip fracture and prevalence of osteoporosis in Turkey: the FRACTURK study. Osteoporos Int 2012;23(3):949-55. (PMID:21594756).

15. Cheung EY, Ho AY, Lam KF, Tam S, Kung AW. Determinants of bone mineral density in Chinese men. Osteoporos Int 2005;16(12):1481-6. (PMID:16133639).

16. Fu X, Ma X, Lu H, He W, Wang Z, Zhu S. Associations of fat mass and fat distribution with bone mineral density in pre- and postmenopausal Chinese women. Osteoporos Int 2011;22(1):113-9. (PMID:20306018).

17. Villareal DT, Shah K, Banks MR, Sinacore DR, Klein S. Effect of weight loss and exercise therapy on bone metabolism and mass in obese older adults: a oneyear randomized controlled trial. J Clin Endocrinol Metab 2008;93(6):2181-7. (PMID:18364384).

18. Boyanov M, Bakalov D, Boneva Z. Bone mineral density in men with and without the metabolic syndrome. Aging Male 2009;12(2-3):62-5. (PMID:19639517).

19. Yang YJ, Kim J. Factors in relation to bone mineral density in Korean middle-aged and older men: 2008-2010 Korea National Health and Nutrition Examination Survey. Ann Nutr Metab 2014;64(1):509. (PMID:24851837).

20. Korkor AB, Eastwood D, Bretzmann C. Effects of gender, alcohol, smoking, and dairy consumption on bone mass in Wisconsin adolescents. WMJ 2009;108(4):181-8. (PMID:19753823).

21. Hollenbach KA, Barrett-Connor E, Edelstein SL, Holbrook T. Cigarette smoking and bone mineral density in older men and women. Am J Public Health 1993;83(9):1265-70. (PMID:8363002). 
22. Oncken C, Prestwood K, Kleppinger A, Wang $Y$, Cooney J, Raisz L. Impact of smoking cessation on bone mineral density in postmenopausal women. J Womens Health (Larchmt) 2006;15(10):1141-50. (PMID:17199455).

23. Pagonis T, Givissis P, Pagonis A, Petsatodis G, Christodoulou A. Osteoporosis onset differences between rural and metropolitan populations: correlation to fracture type, severity, and treatment efficacy. J Bone Miner Metab 2012;30(1):85-92. (PMID:21667356).

24. Nilsson M, Ohlsson C, Odén A, Mellström D, Lorentzon M. Increased physical activity is associated with enhanced development of peak bone mass in men: a five-year longitudinal study. J Bone Miner Res 2012;27(5):1206-14. (PMID:22247082).

25. Chen YT, Miller PD, Barrett-Connor E, Weiss TW, Sajjan SG, Siris ES. An approach for identifying postmenopausal women age $50-64$ years at increased short-term risk for osteoporotic fracture. Osteoporos Int 2007;18(9):1287-96. (PMID:17464525).

26. Assantachai $P$, Angkamat $W$, Pongpim $P$, Weattayasuthum C, Komoltri C. Risk factors of osteoporosis in institutionalized older Thai people. Osteoporos Int 2006;17(7):1096-102. (PMID:16544053).
27. Reid IR. Vitamin D Effect on Bone Mineral Density and Fractures. Endocrinol Metab Clin North Am 2017;46(4):935-45. (PMID:29080644).

28. Moreira ML, Neto LV, Madeira M, Lopes RF, Farias MLF. Vitamin D Deficiency and Its Influence on Bone Metabolism and Density in a Brazilian Population of Healthy Men. J Clin Densitom 2018;21(1):91-7. (PMID:28233710).

29. Khashayar P, Aghaei Meybodi HR, Rezai Hemami M, Keshtkar A, Dimai HP, Larijani B. Vitamin D status and its relationship with bone mineral density in a healthy Iranian population. Rev Bras Ortop 2016;51(4):454-8. (PMID:27517026).

30. Sundh D, Mellström D, Ljunggren Ö, et al. Low serum vitamin $\mathrm{D}$ is associated with higher cortical porosity in elderly men. J Intern Med 2016;280(5):496-508. (PMID:27196563).

31. Fink HA, Litwack-Harrison S, Taylor BC, et al. Clinical utility of routine laboratory testing to identify possible secondary causes in older men with osteoporosis: the Osteoporotic Fractures in Men (MrOS) Study. Osteoporos Int 2016;27(1):331-8. (PMID:26458388). 